\title{
Development of Flip Book Learning Media Based on a Scientific Approach to Improve Reasoning and Understanding Ability Student Mathematics Concepts
}

\author{
Talitha Sikalei, Hermawan Syahputra, Mukhtar \\ Medan State University Postgraduate
}

\begin{abstract}
This study aims to: 1) see the quality (valid, practical and effective) of flip book learning media that was developed to improve students' reasoning abilities and understanding of mathematical concepts; 2) improve students' reasoning abilities and understanding of mathematical concepts through flip book learning media developed. This research is a development research. The development model used in this study is the ADDIE model with 29 students in class VII-A and 23 students in class VII-B at SMP Harapan 1 Medan. The validity of the learning media developed was reviewed from the analysis of the results of the validity of the learning media by the validators with a total average value of 3.73 ("Valid" category). Meanwhile, The practicality of learning media is seen from the observation score of the implementation of learning in the second trial, which is 3.73 (category "Well Implemented"). The effectiveness of learning media in terms of four aspects, namely classical completeness, student activity observation scores, and student responses. The classical completeness of students' reasoning abilities and understanding of mathematical concepts in the second trial was $87 \%$ ( 23 students). The average percentage of students' achievement in the ideal time of activity in the second trial for three meetings was $21.8 \%, 19.2 \%, 21.5 \%, 26.0 \%, 9.8 \%$, and $1.8 \%$. The average student response in the second trial was $91.6 \%$ (category "Interested"). Based on the normalized gain index, it was found that in the second trial there was an increase in the score with a score of 0.4 (the "medium" criterion). The effectiveness of learning media in terms of four aspects, namely classical completeness, student activity observation scores, and student responses. The classical completeness of students' reasoning abilities and understanding of mathematical concepts in the second trial was $87 \%$ (23 students). The average percentage of students' achievement in the ideal time of activity in the second trial for three meetings was $21.8 \%, 19.2 \%, 21.5 \%, 26.0 \%, 9.8 \%$, and $1.8 \%$. The average student response in the second trial was $91.6 \%$ (category "Interested"). Based on the normalized gain index, it was found that in the second trial there was an increase in the score with a score of 0.4 (the "medium" criterion). The effectiveness of learning media in terms of four aspects, namely classical completeness, student activity observation scores, and student responses. The classical completeness of students' reasoning abilities and understanding of mathematical concepts in the second trial was $87 \%$ (23 students). The average percentage of students' achievement in the ideal time of activity in the second trial for three meetings was $21.8 \%, 19.2 \%, 21.5 \%, 26.0 \%$, $9.8 \%$, and $1.8 \%$. The average student response in the second trial was $91.6 \%$ (category "Interested").
\end{abstract}

Keywords: flipbook, Scientific Approach, Reasoning Ability, Mathematical Concept Understanding Ability, Mathematics Learning Media Development, Comparison

DOI: $10.7176 / \mathrm{JEP} / 12-26-05$

Publication date:September $30^{\text {th }} 2021$

\section{PRELIMINARY}

Education plays a very important role for the survival of human life. Education is a means of shaping the human personality in acquiring knowledge and skills from teachers to students to achieve predetermined goals. Education plays an important role in improving the quality of human resources, so it is necessary to make efforts to improve and improve the quality of services in the field of education. This is in line with Aisyah (2014) which states that education has a great influence in determining the quality of human resources. Through education, human resources are prepared. If the education applied is of high quality, then the human resources produced are also of high quality.

Education is said to be of quality if the teaching and learning process can run smoothly, effectively, efficiently and there is interaction between the components contained in the teaching system. The educational paradigm that used to be conventional is now starting to shift to technology-based education. These changes include teaching methods, learning references, learning media and so on. In this technological era, it is possible for students to know more than their teachers.

The existence of these problems will bring consequences for teachers to be more creative in the learning process. Where the ongoing learning process is still focused on the teacher, so students tend to be passive. The teacher who dominates the learning activities in the classroom. In addition, there are still conventional methods that are applied, making the learning atmosphere in the classroom monotonous, Sumarsih (2019). So it is expected that teachers provide more variety in the teaching and learning process so that learning is more 
effective. The learning process will run effectively if all the components involved in it support each other in achieving the learning objectives. These components are in the form of learning materials, teaching methods, media, and evaluation (Saidiman in Mustamine, 2019).

Advances in technology today can affect the field of education to help achieve effective and efficient learning. Education in the current technological era requires teachers to innovate in order to provide a new atmosphere in the learning environment. The demands of the era of globalization with technological developments can be utilized for the development of learning. One way to use technology in learning is the use of technological resources as a medium in the learning process (Akhmadan, 2017). Karimah (2017) states that the mathematics learning process will be more fun, and more interactive by using learning media.

According to Tafonao (2018), learning media are everything that can be used to channel the sender's message to the recipient, so that it can stimulate the thoughts, feelings, concerns, and interests of students to learn. Learning media in accordance with the needs of learning activities will create an effective and efficient learning activity so that the material presented by the teacher to students can be absorbed optimally. The role of learning media in the learning and teaching process is an integral part that cannot be separated from the world of education. Wicaksono (2016) states that the role of the media is very important in the learning process so that the material delivered by the teacher arrives quickly and is easily accepted by students to the maximum. The absence of learning media can hinder the learning process (Sumarsih, 2016). However, after observing until now there are still many teachers who pay less attention to learning media. This is due to the lack of awareness of the importance of learning media in the teaching and learning process. The process of making learning media takes more time and is a little difficult so it needs awareness for teachers to develop and use learning media in order to improve the quality of learning in the teaching and learning process because learning media contribute to improving the quality and quality of learning.

This can also be seen from the results of interviews with one of the mathematics teachers at SMP Harapan 1 Medan, such as: "Actually, I want to use learning media that attracts students' attention, but making this learning media takes more time and is sometimes a little difficult. Not yet with student assignments and so on, so it will take a lot of time for that." Therefore, he is required to develop a learning media that can support the learning process and improve the quality of learning. Lack of development of media used by teachers to improve reasoning skills and understanding of concepts is also common. As a result, students are unable to reason and understand the concepts presented in the learning process.

Flip Bookis one of the technologies that can be used in learning activities. Flip Book is a multimedia-based learning media that can be used in the mathematics learning process. Diena et al (2010) stated that Flip Book is a classic animation made from a pile of paper resembling a thick book, each page describes a process about something which later on the process looks animated. This helps increase students' mastery of abstract things or events that cannot be presented in class. Thus, it will help students in their reasoning abilities where this application is also still rarely used in schools.

Wahyudin (2008) stated that the ability to use reasoning is very important to understand mathematics and become a permanent part of students' mathematical experience. Tukaryanto (2018) says that the importance of mathematical reasoning skills greatly influences the mathematics learning process they follow. Because students who have good reasoning abilities will easily understand mathematical material and vice versa students with low mathematical reasoning abilities will have difficulty understanding mathematical material. Mathematical reasoning ability is the ability to analyze new situations, generalize, synthesize, make logical assumptions, explain ideas, give good reasons and make conclusions. By reasoning, Students can develop their thoughts and channel their aspirations and opinions in oral and written form. So that mathematics lessons and mathematical reasoning are two related things, namely solving mathematical problems requires reasoning and reasoning abilities can be honed from learning mathematics. Research by Widayanti \& Kolbi (2018) which shows that in working on the TIMSS questions, the reasoning category of students' abilities is still relatively low and the type of error that is most often experienced is an error in understanding the concept of the question given. Students have not been able to understand the command questions given. Concept understanding is an ability possessed by individuals so that they can provide an understanding of a study. Febriyanto (2018) which states that understanding the concept is very important, because mastering the concept will make it easier for students to learn a subject matter.

Based on the description above, the author is interested in conducting a study related to media and learning approaches, reasoning abilities and students' mathematical concept understanding abilities, entitled "Development of Flip Book Mathematics Learning Media Based on Scientific Approach to Improve Students' Reasoning Ability and Understanding of Mathematical Concepts".

\section{METHOD}

This research was conducted at SMP Harapan 1 Medan in the odd semester of the 2021/2022 academic year. The subjects in this study were students of class VII-A and VII-B of SMP Harapan 1 Medan. The object in this study 
is a flip book learning media based on a scientific approach to comparative material. This type of research is Research and Development using the ADDIE model.

\section{Data collection}

The data collection instrument consisted of a validation sheet that was used to obtain data on the quality of learning devices based on the assessment of experts. Some of the validation sheets used include: validation sheets for learning media experts; validation sheet for Learning Implementation Plan (RPP); validation sheet for Student Worksheet (LKPD). Then for the practicality questionnaire filled out by students and tests of students' reasoning abilities and understanding of mathematical concepts.

The data obtained from the results of the test of reasoning ability and understanding of mathematical concepts were analyzed to determine the improvement. The data were obtained from the results of the pre-test and post-test of students' reasoning abilities and understanding of mathematical concepts. To calculate the increase in students' reasoning abilities and understanding of mathematical concepts, the n-gain value is determined first. In calculating n-gain, the formula is used (Lestari and Yudhanegara, 2015: 235):

Normalized gain $=\frac{S_{\text {post }}-S_{\text {pra }}}{S_{\max }-S_{\text {pre }}}$

Information:

$N-$ Gain $=$ normalized gain score

$S_{\text {post }}=$ final test score

$S_{\text {pre }} \quad=$ preliminary test scores

maximum score $S_{\max } \quad=$

Table 1.

N-Gain Score Criteria

\begin{tabular}{cc}
\hline Gain Score $(\mathbf{g})$ & Criteria \\
\hline $\mathrm{g} 0.3 \leqq$ & Low \\
\hline $0.3<\mathrm{g} 0.7 \leqq$ & Currently \\
\hline $\mathrm{g}>0.7$ & Tall \\
\hline
\end{tabular}

Source: (Hake, 1999)

RESULTS AND DISCUSSION

Validity of Interactive Digital Book Learning Media

Table 2.

Summary of the Validation Results of Flip Book Learning Media and Validated Learning Instruments

\begin{tabular}{lcc}
\hline \multicolumn{1}{c}{ Validated Instrument } & Score & Category \\
\hline Learning Media & 3.73 & Valid \\
\hline Lesson plan (RPP) & 3.74 & Valid \\
\hline Student Worksheet (LKPD) & 3.81 & Valid \\
\hline Initial test of mathematical reasoning ability & 3.85 & Valid \\
\hline Final test of mathematical reasoning ability & 3.73 & Valid \\
\hline Initial test of the ability to understand mathematical concepts & 3.85 & Valid \\
\hline Final test of the ability to understand mathematical concepts & 3.89 & Valid \\
\hline
\end{tabular}

\section{Practicality of Flip Book Learning Media}

The practicality of developing flip book learning media has met the practical criteria in terms of the results of the assessment of the experts (validators), all validators stated that the flip book learning media developed was feasible to use with slight revisions. Then, observe the implementation of learning using flip book learning media in table 3 below:

Table 3.

Summary of Observation Results of Learning Implementation

\begin{tabular}{|c|c|c|c|c|c|c|c|c|}
\hline & \multicolumn{4}{|c|}{ Trial I } & \multicolumn{4}{|c|}{ Trial II } \\
\hline & I & II & III & IV & I & II & III & IV \\
\hline Score & 2.67 & 2.8 & 2.74 & 2.8 & 3.53 & 3.8 & 3.8 & 3.8 \\
\hline Average & \multicolumn{4}{|c|}{2.75} & \multicolumn{4}{|c|}{3.73} \\
\hline Category & \multicolumn{4}{|c|}{ Implemented Poorly } & \multicolumn{4}{|c|}{ Well done } \\
\hline
\end{tabular}

Based on the table, it can be seen that the learning implementation observation score did not meet the 
practicality criteria in the first trial, namely with an average score of 2.75 in the first trial (category "Implemented Poorly"). While in the second trial, an average score of 3.73 was obtained in the "Well Implemented" category.

\section{The Effectiveness of Flip Book Learning Media}

Reasoning Ability Test Achievement and Understanding of Mathematical Concepts

Based on the results of the test analysis in trials I and II, it was found that the students' reasoning abilities had met the classical completeness criteria. The description of the results of students' reasoning abilities is shown in table 4 below:

Table 4.

Summary of Reasoning Ability and Concept Understanding Achievement Test

\begin{tabular}{ccc}
\hline \multirow{2}{*}{ Trials } & \multicolumn{2}{c}{ Achievement on } \\
\cline { 2 - 3 } & Reasoning Ability & Concept Understanding Ability \\
\hline I & $55.2 \%$ & $55.2 \%$ \\
\hline II & $87 \%$ & $87 \%$ \\
\hline
\end{tabular}

The achievement of the final test of students' reasoning ability and understanding of mathematical concepts in the first trial was $55.2 \%$ with 16 students declared complete. So, it can be concluded that in the first trial the application of the developed flip book learning media did not meet the criteria for achieving classical completeness $(>80 \%)$. However, in the second trial, the achievement of the final test of reasoning ability and understanding of mathematical concepts of students has met the specified criteria, which is $87 \%$ with a total of 20 students declared complete. Thus, it can be said that the flip book learning media has met the effectiveness criteria in the aspect of achieving students' reasoning abilities and understanding of mathematical concepts.

\section{Student Activities}

Based on the results of the first trial, it can be concluded that all student activities meet the ideal percentage of time set. The summary can be seen in table 5 below:

Table 5.

Summary of Ideal Time Percentage of Student Activities in Trials I and II

\begin{tabular}{|c|c|c|c|c|}
\hline Observation Aspect & $\begin{array}{c}\text { Trial } \\
\text { Average I }\end{array}$ & $\begin{array}{l}\text { Trial Average } \\
\text { II }\end{array}$ & $\begin{array}{c}\text { Time } \\
\text { Ideal } \\
(\%)\end{array}$ & Tolerance \\
\hline $\begin{array}{l}\text { Observing the presentation of material with learning } \\
\text { media }\end{array}$ & 21.8 & 21.8 & 20 & $\begin{array}{l}15 \% \text { PWI } \\
25 \% \leq \leq\end{array}$ \\
\hline Asking problems in learning media or LKPD & 18.4 & 19.2 & 30 & $\begin{array}{l}25 \% \text { PWI } \\
35 \% \leq \leq\end{array}$ \\
\hline Looking for information to add insight into the material & 20.9 & 21.5 & 30 & $\begin{array}{l}25 \% \mathrm{PWI} \\
35 \% \leq \leq\end{array}$ \\
\hline Reasoning/associating learning and presented LKDP & 26.0 & 26.0 & 10 & $\begin{array}{l}5 \% \text { PWI } \\
15 \% \leq \leq\end{array}$ \\
\hline $\begin{array}{l}\text { Communicating about the learning process, results and } \\
\text { conclusions }\end{array}$ & 10.7 & 9.8 & 10 & $\begin{array}{l}5 \% \text { PWI } \\
15 \% \leq \leq\end{array}$ \\
\hline Doing activities that are not relevant to learning & 3.0 & 1.8 & 0 & $\begin{array}{l}0 \% \text { PWI } \\
15 \% \leq \leq\end{array}$ \\
\hline
\end{tabular}

Based on the analysis of the results of observation of student activities in the first trial, it was obtained that the average percentage of achieving the ideal time for student activities for the four meetings in the first trial was $21.8 \%, 18.4 \%, 20.9 \%, 26 \%, 10.7 \%$, and $3 \%$. While the results of the second trial, the average percentage of students' ideal time for four meetings in the first trial was $21.8 \%, 19.2 \%, 21.5 \%, 26 \%, 9.8 \%$, and $1,8 \%$. It can be concluded that all student activities meet the set ideal percentage of time.

\section{Student Response}

Based on the analysis of the results of student responses, it was found that in the first and second trials, students were interested in the learning media developed. More clearly, the data is shown in Table 6 below: 
Table 6.

Summary of Student Response Questionnaire Analysis Results

\begin{tabular}{ccccc}
\hline \multirow{2}{*}{ Respondent } & \multicolumn{2}{c}{ Trial I } & \multicolumn{2}{c}{ Trial II } \\
\cline { 2 - 5 } & $\%$ Average Score & Category & \% Average Score & Category \\
\hline Student & $90.4 \%$ & Interested & $91.6 \%$ & Interested \\
\hline
\end{tabular}

This can be seen from the average score of student responses showing interest in learning with the developed learning media. Judging from the percentage of student response questionnaire scores in the first trial of $90.4 \%$ with the interested category and in the second trial it was $91.6 \%$ with the interested category. So it can be concluded that from the student's response to the flip book learning media that was developed effectively.

\section{Improvement of Reasoning Ability and Understanding of Mathematical Concepts}

Based on the results of the analysis of the students' reasoning ability and understanding of mathematical concepts in the first and second trials, it showed that there was an increase. The scores for increasing students' reasoning ability and understanding of mathematical concepts in the first and second trials can be seen in table 7 below:

Table 7.

Improving Students' Reasoning Ability and Understanding of Mathematical Concepts

\begin{tabular}{cccccc}
\hline & \multicolumn{2}{c}{ Reasoning Ability } & \multicolumn{2}{c}{ Concept } & Understanding Ability \\
\hline & Trial I & Trial II & & Trial I & Trial II \\
\hline Score & 0.3 & 0.4 & Score & 0.3 & 0.4 \\
\hline Category & Low & Currently & Category & Low & Currently \\
\hline
\end{tabular}

Based on the average normalized gain, it was found that in the first trial there was an increase in the reasoning ability and understanding of mathematical concepts of students with low criteria with a score of 0.3 $(\mathrm{N}-$ Gain $)$ and in the second trial there was an increase in scores with moderate criteria with a score of $0,4(0.3<$ $\mathrm{N}-$ Gain . So it can be concluded that the developed flip book learning media can improve students' reasoning

abilities and understanding of mathematical concepts. $\leq 0,3 \leq 0,7)$

Based on the results of the validation of the developed flip book learning media, it was found that this learning media was valid or had a good degree of validity. Furthermore, the results of the validation of the lesson plan (RPP), student worksheets (LKPD), pretest and posttest of reasoning ability and understanding of mathematical concepts are also valid. This means that the learning media and its devices can meet the demands of learning needs to improve reasoning abilities and understanding of concepts in comparative material. Based on the results of the validation carried out by learning media experts, a score of 3.73 was obtained with the "Valid" category of the developed flip book learning media. So that the flip book learning media that was developed fulfills the demands of learning needs for comparative subject matter. This is supported by the opinion of Rozak, Darmadi, and Murtafi'ah (2018: 40) that the learning media meets the criteria of validity if it is said to be valid by the validator. In addition, Arsyad (2017: 75) says that one of the criteria for media that is worth choosing is media that is aligned and in accordance with the needs of the learning task. This opinion is also supported by Sutikno (2013: 112) who says that media is appropriate to use if it supports the content of learning materials. So it can be concluded that the developed flip book learning media has met the validity indicators. 75) who said that one of the criteria for media that deserves to be selected is media that is aligned and in accordance with the needs of the learning task. This opinion is also supported by Sutikno (2013:112) who says that media is appropriate to use if it supports the content of learning materials. So it can be concluded that the developed flip book learning media has met the validity indicators. 75) who said that one of the criteria for media that deserves to be selected is media that is aligned and in accordance with the needs of the learning task. This opinion is also supported by Sutikno (2013: 112) who says that media is appropriate to use if it supports the content of learning materials. So it can be concluded that the developed flip book learning media has met the validity indicators.

The results of the assessment of the experts (validators), all validators stated that the flip book learning media developed was feasible to use with a few revisions. This is supported by the opinion of Akker (2007: 66) which states that the criteria for the practicality of learning media are said to be practical if the validator assesses that what is developed can be applied. This is in line with the research of Annisa, Putra, and Dharmono (2020: 78) which states that the practicality of learning media is important to know because one of the requirements for learning media is that it is easy to use by users.

Hasratuddin (2018: 242) states that the indicator of learning effectiveness is based on the achievement of mastery learning if $>80 \%$ of students have completed, the time used in learning is efficient or does not exceed ordinary learning, and student responses to positive learning. Based on the results of trial I and trial II, the developed learning media has met the effective category in terms of the achievement of students' reasoning abilities and understanding of mathematical concepts, active student activities, and positive responses from students. As forThe posttest achievement of the students' reasoning abilities and understanding of mathematical 
concepts in the first trial was the same, which was $55.2 \%$ with a total of 16 students who were declared complete. So, it can be concluded that in the first trial the application of the developed flip book learning media did not meet the criteria for achieving classical mastery $(>80 \%)$. by $867 \%$ with a total of 20 students declared complete. Thus, it can be said that the flip book learning media has met the effectiveness criteria in the aspect of achieving students' reasoning abilities and understanding of mathematical concepts.

Based on the analysis of the results of observing student activities in the first trial, the average percentage of achievement of the ideal time of student activity for two meetings in the first trial was obtained is $21.7 \%, 18.4 \%$, $20.9 \%, 26.0 \%, 10.7 \%$ and 3.0\%. Meanwhile, in the second trial, the average percentage of students' achievement in the ideal time for three meetings was $21.8 \%, 19.2 \%, 21.5 \%, 26.0 \%, 9.8 \%$ and $1.8 \%$. Based on these data, it can be concluded that all student activities in the second trial also meet the ideal percentage of time set.

The results of the analysis of the results of student responses that have been described previously, it was found that in the first and second trials, students were interested in the learning media developed. This can be seen from the average score of student responses showing interest in learning with the developed learning media. Judging from the average score of the student response questionnaire in the first trial of 90.4 with the interested category and in the second trial it was $91.6 \%$ with the interested category. So it can be concluded that from the student's response to the interactive digital book learning media that was developed effectively. According to Arsyad (2017: 25) learning using learning media is considered to attract attention and keep students awake and paying attention. In other words, learning media is able to make teaching and learning activities in the classroom effective.From the description of all aspects of the effectiveness of the learning media above, it can be concluded that the flip book learning media developed is effective for use in learning comparative material to improve students' reasoning abilities and understanding of mathematical concepts.

Based on the results of the analysis of students' reasoning ability tests in the first and second trials, it showed that there was an increase. Based on the average normalized gain, it was found that in the first trial there was an increase in the reasoning ability of students with the "low" criteria with a score of 0.3 (N-Gain) and in the second trial there was an increase in the value with the "medium" criteria with a score of $0,4(0.3<\mathrm{N}$-Gain . So it can be concluded that the developed flip book learning media can improve students' reasoning abilities and

understanding of mathematical concepts. $\leq 0,3 \leq 0,7)$

\section{REFERENCES}

Akhmadan, W. (2017). Development of Line and Angle Teaching Materials Using Macromedia Flash and Moodle for Grade VII Junior High School. Bushel Journal, 2(1), 27-40.

Akker, JVD (2007). An Introduction to Educational Design Research. Proceedings of The Seminar Conducted at The East China Normal University, Shanghai (PR China). November 23-26.

Anggraeni, E., R. (2021). Development of Geogebra-Based Mathematics Learning Media to Improve Students' Concept Understanding Ability. Journal of Mathematics Research and Mathematics Education. Vol.4 No 1. Pg.43-55

Annisa, A, R., Putra, A., \& Dharmono. (2020). Practicality of Learning Media Anti-Bacterial Power of Sawo Fruit Extract Based on Macromedia Flash. Quantum: Journal of Science Education Innovation, 11(1).

Arcat., Afri, E, L., (2017), Students' Reasoning Ability, Scientific Journal of Edu Research, VI(2): 34-42.

Arigayati, AT, (2017), Differences in Mathematical Reasoning Ability in Learning Cycle Models and Conventional, Journal of Math Educator Nusantara (JMEN), III(1): 43-51.

Arsyad, A. (2017). Learning Media. Jakarta: PT Raja Grafindo Persada.

Azriati, S, A., Syahputra, E., \& Sumarno. (2018). Development of Macromedia Flash-Based Mathematics Learning Media to Improve Students' Spatial Ability. Paradikma Journal of Mathematics Education, 11(1): 2502-7204.

Hamalik, O. (2008). Teaching Planning Based on Systems Approach. Jakarta: Earth Literacy.

Haryanto. (2015). Education technology. Yogyakarta: UNY Press

Hendriana, H., et al. (2017). Students' Mathematics Hard Skills and Soft Skills. Bandung: PT Refika Aditama. Hasratuddin. (2018). Why Should You Learn Maths. Medan: Perc. Edira.

Jihad, Asep and Abdul Haris. 2008. Learning Evaluation. Yogyakarta: Multi Pressindo. Ar-Ruzz Media Group. Kuswana, Wowo Sunaryo. 2011. Taxonomy of Thinking. Bandung: Rosda.

Marselina, V., \& Muhtadi, A. (2019). Development of Interactive Mathematics Digital Books on Geometry Materials. Journal of Educational Technology Innovation, 6(2): 196-207.

Ningsih, Y, L. (2016). Students' Ability to Understand Mathematical Concepts Through Application of TheoryBased Student Activity Sheets (LAM) on Derivative Materials. Journal of Edumatica. Vol 6 (1), pp. 1-8.

Pramusinta, N., Rejeki, S., (2017), Improving Students' Mathematical Reasoning Ability, Journal of Mathematics Education (JMP), III (2):1-6.

Rahmawati, D., Wahyuni, S., \& Yushardi. (2017). Development of Flipbook Learning Media on the Material of 
Motion of Objects in Junior High School. Journal of Physics Learning. 6(4), 326-332

Rusnilawati, \& Gustiana, E. (2017). Development of Flipbook-Assisted Electronic Teaching Materials (BAE) Based on Problem Solving Skills Using the NCTL Approach in Class V Mathematics Learning Primary school. Basic Education Profession, 4(2):191.

Rosita, DC, (2015), Mathematical Reasoning and Communication Skills: What, Why, and How to be Improved in Students, Euclid Journal, I(1): 1-59.

Rozak, A., Darmadi, \& Murtafi'ah, W. (2018). Development of SASA-AURA Learning Media to improve student achievement at SMK Cendekia Madiun for the 2017/2018 Academic Year. Journal of Education and Science, 18(1): 2614-0578.

Sabina. (2019). Application of Discovery Learning with Scientific Approach in Improving Concept Understanding Ability and Mathematical Reasoning Ability and Its Impact on Self Regulated Learning of Junior High School Students. Civil Journal. Vol 2 No.2 Pg. 2001-215

Sonda, R., Alimuddin, \& Asdar. (2016). Effectiveness of Realistic Mathematics Learning (PMR) Cooperative Setting Type of NHT on Similarity Materials for Class IX Students of SMP Negeri 1 Simbuang. Journal of Mathematical Power,4(1): 1-12.

Sumarsih, d. M. (2016). Multimedia Development Cost Accounting Method Ordered Diaper Prices for Accounting Education Department Students UNY. Journal of Educational Technology Innovation, 3(1), 92-105.

Sundayana, R. 2013. Mathematics learning media, PT. Alphabeta, Bandung.

Susilana, R \& Cepy, R. (2016). Learning Media. Bandung: CV Wacana Prima.

Sutikno, S. (2013). Study and Learning. Lombok: Hollistica.

Syarif, H., \& Rakhmawati, L. 2016. Development of Flip Book Maker-based Learning Media in Basic Electrical Lessons at SMKN 1 Sampang. Journal of Mathematics FMIPA UNNESS No. 02, Vol. 03.

Tukaryanto, Putriaji Hendikawati, Sugeng Nugroho. 2018. Improving Mathematical Reasoning Ability and Confidence of Class X Students Through Discovery Learning Model. PRISMA, Proceedings of the National Mathematics Seminar.

Utami, PN, Mukhni., Jazwinarti., (2014), Students' Mathematical Reasoning Ability, Journal of Mathematics Education, III(1): 7-12.

Wahyudin. (2008). Learning and Learning Models. Bandung: UPI Press. Mofidi et al. (2012). "Instruction of mathematical concepts through analogical reasoning skills". Ibdian Journal of Science and Technology, 5, (6), 2916-2922

Wibowo, TP (2014). Development of Multimedia Book Electronic Teaching Materials on Life Organization System Materials in Junior High School. Unnes Journal of Biology Education, 3(1).

Wicaksono, S. (2016). The Development Of Interactive Multimedia Based Learning Using Macromedia Flash 8 In Accounring Course. Journal of Accounting and Business Education, 1(1), 122-139

Yuliani, et al. (2018). The Ability of Understanding Mathematical Concepts of Class VIII Students of SMP 1 Kuok Through Cooperative Learning Model Type of Group Investigation. Journal of Mathematics Education. Vol. 2. No. 2. Pg. 91-100. 